\title{
Dinoflagellate Cysts in the Surface Sediments of the White Sea
}

\author{
E. A. Novichkova ${ }^{a}$ and E. I. Polyakova ${ }^{b}$ \\ a Shirshov Institute of Oceanology, Russian Academy of Sciences, Moscow, Russia \\ ${ }^{b}$ Faculty of Geography, Moscow State University, Moscow, Russia \\ e-mail:enovichkova@mail.ru \\ Received June 7, 2004; in final form, July 19, 2006
}

\begin{abstract}
Dinoflagellate cysts were studied in 42 samples from the surface sediments of the White Sea. The total concentration of dinocysts varies from single cysts to $25000 \mathrm{cyst} / \mathrm{g}$ of dry sediments, which reflects the biological productivity in the White Sea waters and the regional particular features of the sedimentation processes. The highest concentrations are observed in silts; they are related to the regions of propagation of the highly productive Barents Sea waters in the White Sea. Generally, the spatial distribution of dinocysts species in the surface sediments corresponds to the distribution of the major types of water masses in the White Sea. The cysts of the relatively warm-water species (Operculodinium centrocarpum, Spiniferites sp.) of North Atlantic origin that dominate in the sediments indicate an intensive intrusion of the Barents Sea water masses to the White Sea along with hydrological dwelling conditions in the White Sea favorable for the development of these species during their vegetation period. The cold-water dinocyst assemblage (Islandinium minutum, Polykrikos sp.) is rather strictly confined to the inner parts of shallow-water bays, firstly, those adjacent to the Onega and Severnaya Dvina river mouths.
\end{abstract}

DOI: $10.1134 / \mathrm{S} 0001437007050086$

\section{INTRODUCTION}

Up to recently, the micropaleontological groups that have been leading in the stratigraphic and paleoceanological studies of the Arctic seas were almost exclusively diatoms; foraminifers; spores and pollen; and, partly, ostracodes. During the past years, the microfossil group included, first of all, dinoflagellate cysts, green algae, acritarchs, and organic portions of foraminifer skeletons and other organic remains of aquatic microorganisms [28, 34, 36]. Among the aquatic objects, the most informative for paleoceanological reconstructions are cysts of dinoflagellates (dinocysts), which allow one to reconstruct various parameters of the water masses such as the temperature and salinity of the surface seawaters, the presence of sea ice, and the origin and distribution of the main types of water masses [27, 35]. Freshwater green algae, along with their quantitative relation to dinoflagellate cysts, may be used as indicators of the riverine runoff and changes in its intensity [34].

Dinoflagellates-unicellular microorganisms with a wide food spectrum - are, together with diatoms, one of the principal components of the phytoplankton of the shelf Arctic seas [18]. Meanwhile, only one-fifth of them form cysts that can be conserved in the sediments $[30,34]$. In the recent years, the studies of the dinocysts of the Arctic seas have made great progress and allowed scientists to reveal the general regularities of their composition and distribution in the bottom sediments depending on the hydrological and ice conditions of the shelf $[26,30,31,35,40,46]$. Up to the present, for this group of microfossils with different degrees of detailing, the characteristics of the species and quantitative compositions of their assemblages in the sediments of almost all of the Arctic seas have been obtained except for in the East Siberian and White seas. Thus, the results of dinocyst studies in the surface sediments of the White Sea presented in this paper represent the first information on the group considered, which allows one to use it in the paleoenvironmental reconstructions of the White Sea.

\section{MATERIALS AND METHODS}

This report is based on the materials collected during cruise 49 of R/V Professor Shtokman on August 2-22, 2001; the cruise of R/V Ekolog in September 2002; and in the expedition of R/V Ivan Petrov in July 2002 in the White Sea. The collection and lithological description of the samples were performed by the scientists of the Laboratory of Physical-Geological Studies of the Shirshov Institute of Oceanology of the Russian Academy of Sciences. A total of 42 samples of the surface $(0-5 \mathrm{~cm})$ sediments were selected for the analyses (Fig. 1, Table 1); the preliminary results of their processing were partly published [39]. The samples were collected with the use of an Okean- 0.25 grab sampler and placed in plastic bags. After vacuum drying executed at the Schmidt Russian-German Laboratory of the Arctic and Antarctic Research Institute (AANII) in St. Petersburg, subsequent processing was performed 


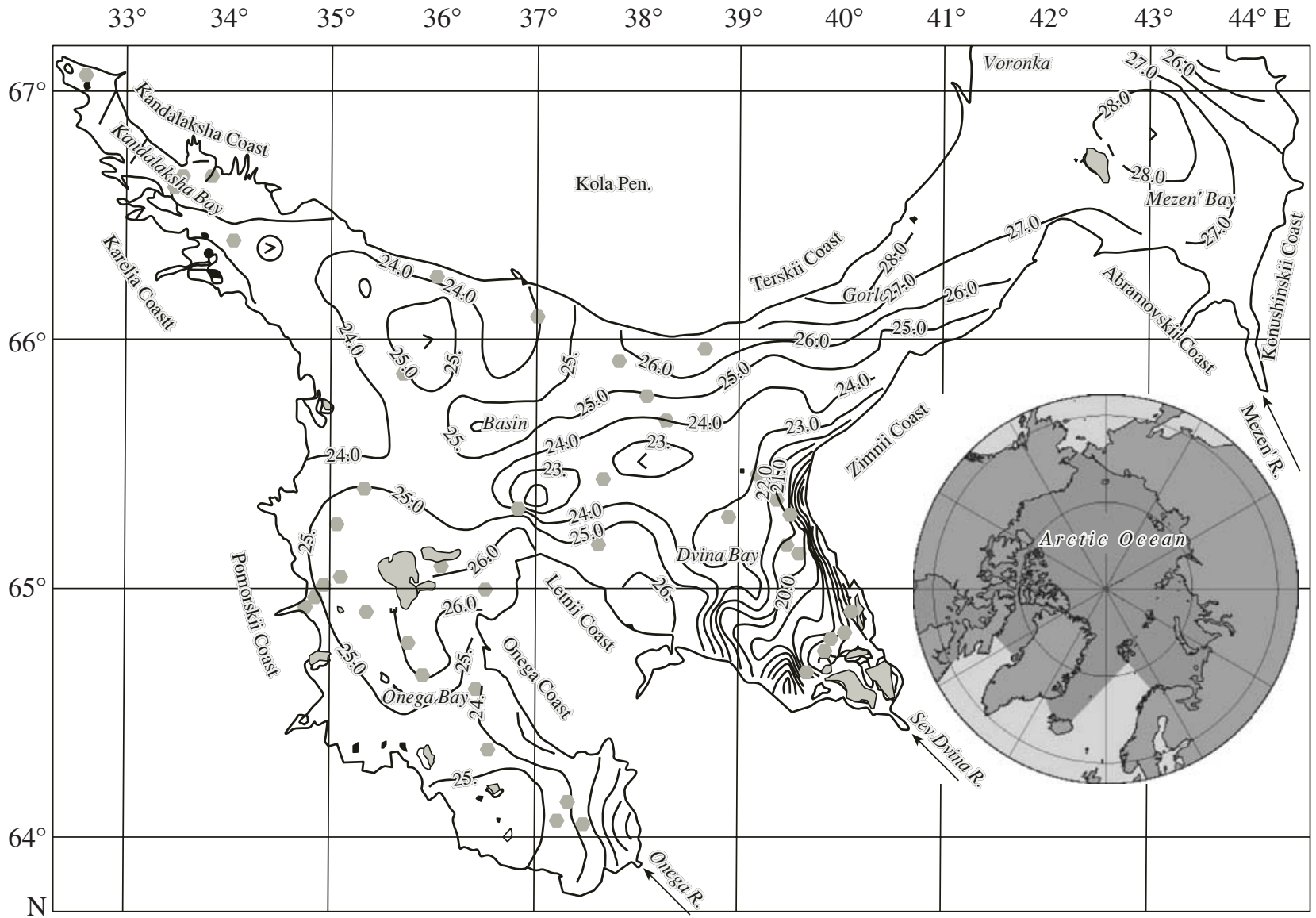

Fig. 1. Distribution of the mean interannual summertime salinity of the surface waters of the White Sea [1]. The dots represent the location of the samples of the surface sediments studied (see Table 1 for coordinates).

following the technique applied for the program bottom sediment samples at the Alfred Wegener Institute for Polar and Marine Research (AWI) in Potsdam. According to this technique, in order to dissolve carbonates and silicon-containing particles, $\mathrm{HCl}$ and $\mathrm{HF}$ were used $[23,38]$. To remove particles smaller than $10 \mu \mathrm{m}$ from the sample, the preparations were filtered using filters $47 \mathrm{~mm}$ in diameter with a pore size of $7-10 \mu \mathrm{m}$. The filtered sediment, which contained dinoflagellate cysts, was added to glycerin. The examination of the microfossils was performed with the help of a Neovar 2 light microscope at a magnification of $\times 400$. In each of the samples, at least 100 dinoflagellate cysts were identified. The addition of tablets with spores of Lycopodium clavatum to the preparations allowed us to count the cyst concentration in the sediment (number of cysts per gram of dry sediment) using the method described by Stockmarr [45].

\section{PRESENT-DAY ICE AND HYDROLOGICAL CONDITIONS OF THE WHITE SEA}

The White Sea is almost entirely located south of the Polar Circle. It belongs to the basin of the Arctic Ocean and is the most isolated sea from it (Fig. 1). It is connected with the Barents Sea via a shallow-water strait and has an area of 91 th. $\mathrm{km}^{2}[2,10]$. This minor sea basin is characterized by significant sea depth increments $[2,21,24]$. The average sea depth equals about $67 \mathrm{~m}$; the maximal depths are registered in the central depression (the Basin of the White Sea) and in Kandalaksha Bay, where they reach $350 \mathrm{~m}$. With respect to the structure and geomorphology, one can distinguish the Voronka, the Gorlo, the Basin, and four major bays: Onega, Dvina, Mezen', and Kandalaksha bays. They differ in the regimes of the freshwater supply, influence of tides, salinity gradients, ice conditions, and biota $[2$, $13,29]$.

Presently, within the framework of modern concepts, the White Sea is regarded to represent a hierarchic estuarine system. The upper level of the hierarchy is the entire sea, within which two water masses occur (the White Sea mass with a salinity of $25-30 \%$ and the Barents Sea mass with a salinity of 34-35\%o). When changing the scale of the consideration, the sea becomes a system of four bays-estuaries rather than a single estuary [37]. 
Table 1. Geographical location of the samples studied in the White Sea. The lithological composition of the surface sediments and the concentrations of dinoflagellate cysts are converted to $1 \mathrm{~g}$ of dry sediment

\begin{tabular}{|c|c|c|c|c|}
\hline \multirow{2}{*}{ Sample nos. } & \multicolumn{2}{|c|}{ Coordinates } & \multirow{2}{*}{ Lithological composition of the sediments } & \multirow{2}{*}{$\begin{array}{l}\text { Dinocyst } \\
\text { concentration } \\
\text { (cyst/g of dry } \\
\text { sediment) }\end{array}$} \\
\hline & Latitude, $\mathrm{N}$ & Longitude, E & & \\
\hline \multicolumn{5}{|c|}{ Cruise 49 of R/V Professor Shtokman, August 2001} \\
\hline PSh-4684 & $64^{\circ} 45.65^{\prime}$ & $39^{\circ} 42.40^{\prime}$ & Well washed fine-grained sand & $<100$ \\
\hline PSh-4687 & $64^{\circ} 40.66^{\prime}$ & $39^{\circ} 32.98^{\prime}$ & Fine-grained sand & $<100$ \\
\hline PSh-4693 & $64^{\circ} 48.53^{\prime}$ & $39^{\circ} 46.17^{\prime}$ & Silty fine-grained sand & $<100$ \\
\hline PSh-4694 & $64^{\circ} 48.38^{\prime}$ & $39^{\circ} 54.82^{\prime}$ & Sandy silt & 4200 \\
\hline PSh-4697 & $65^{\circ} 17.03^{\prime}$ & $38^{\circ} 54.90^{\prime}$ & Sandy-clayey silt & 3000 \\
\hline PSh-4699 & $65^{\circ} 40.80^{\prime}$ & $38^{\circ} 16.29^{\prime}$ & Silty-clayey ooze & 2200 \\
\hline PSh-4700 & $65^{\circ} 46.97^{\prime}$ & $38^{\circ} 03.09^{\prime}$ & Liquid silty-clayey warp & 5500 \\
\hline PSh-4701 & $65^{\circ} 55.31^{\prime}$ & $37^{\circ} 50.87^{\prime}$ & Liquid silty-clayey warp & 5200 \\
\hline PSh-4702 & $65^{\circ} 26.09^{\prime}$ & $37^{\circ} 41.98^{\prime}$ & Liquid silty-clayey warp & 5900 \\
\hline PSh-4703 & $65^{\circ} 11.09^{\prime}$ & $37^{\circ} 35.39^{\prime}$ & Liquid silty-clayey warp with an admixture of sand grains & 2500 \\
\hline PSh-4704 & $65^{\circ} 19.07^{\prime}$ & $37^{\circ} 35.39^{\prime}$ & Liquid silty-clayey warp & 10500 \\
\hline PSh-4705 & $65^{\circ} 01.20^{\prime}$ & $36^{\circ} 34.03^{\prime}$ & Silty-clayey warp & $<100$ \\
\hline PSh-4706 & $65^{\circ} 05.24^{\prime}$ & $36^{\circ} 05.47^{\prime}$ & Unsorted silty sand, sometimes gravel & 4700 \\
\hline PSh-4709 & $64^{\circ} 35.29^{\prime}$ & $36^{\circ} 26.94^{\prime}$ & $\begin{array}{l}\text { Pebbles and gravel in the matrix of liquid clayey varigrained } \\
\text { sand }\end{array}$ & 750 \\
\hline PSh-4712 & $64^{\circ} 08.90^{\prime}$ & $37^{\circ} 19.66^{\prime}$ & Weakly clayey sand with coquina and pebbles & 300 \\
\hline PSh-4713 & $64^{\circ} 21.91^{\prime}$ & $36^{\circ} 32.41^{\prime}$ & Unsorted sediment from sand, gravel, and pebbles & $<100$ \\
\hline PSh-4714 & $64^{\circ} 39.30^{\prime}$ & $35^{\circ} 52.65^{\prime}$ & Clayey silty sand & 3000 \\
\hline PSh-4716 & $65^{\circ} 16.24^{\prime}$ & $35^{\circ} 04.83^{\prime}$ & Clayey fine-grained sand & 9500 \\
\hline PSh-4717 & $65^{\circ} 24.19^{\prime}$ & $35^{\circ} 21.13^{\prime}$ & Sandy-clayey silt & 5900 \\
\hline PSh-4719 & $65^{\circ} 51.31^{\prime}$ & $35^{\circ} 43.16^{\prime}$ & Liquid silty clay & 4400 \\
\hline PSh-4720 & $65^{\circ} 57.26^{\prime}$ & $35^{\circ} 53.52^{\prime}$ & Silty-sandy clayey warp & $<100$ \\
\hline PSh-4721 & $66^{\circ} 39.35^{\prime}$ & $33^{\circ} 38.56^{\prime}$ & Strongly clayey medium- and fine-grained sand & 2700 \\
\hline PSh-4722 & $66^{\circ} 35.91^{\prime}$ & $33^{\circ} 29.30^{\prime}$ & Sandy-clayey silt & 5100 \\
\hline PSh-4724 & $66^{\circ} 09.56^{\prime}$ & $35^{\circ} 02.18^{\prime}$ & Silty-clayey warp & 5700 \\
\hline PSh-4728 & $65^{\circ} 21.00^{\prime}$ & $39^{\circ} 21.30^{\prime}$ & Sandy-clayey warp & 3200 \\
\hline \multicolumn{5}{|c|}{ R/V Ekolog, September 2002} \\
\hline 3 & $66^{\circ} 19.80^{\prime}$ & $33^{\circ} 39.84^{\prime}$ & Silt & 10500 \\
\hline 4 & $67^{\circ} 08.10^{\prime}$ & $32^{\circ} 23.20^{\prime}$ & Silt & 7200 \\
\hline 10 & $65^{\circ} 00.53^{\prime}$ & $34^{\circ} 49.84^{\prime}$ & Silty clay with an admixture of coarse-grained sand & $<100$ \\
\hline 15 & $66^{\circ} 39.95^{\prime}$ & $33^{\circ} 50.23^{\prime}$ & Silt & 4600 \\
\hline 16 & $64^{\circ} 58.65^{\prime}$ & $34^{\circ} 47.84^{\prime}$ & Silty clay & $<100$ \\
\hline 32 & $64^{\circ} 06.93^{\prime}$ & $37^{\circ} 35.07^{\prime}$ & Weakly clayey sand with coquina and pebbles & 2500 \\
\hline 40 & $65^{\circ} 02.05^{\prime}$ & $34^{\circ} 53.79^{\prime}$ & Silty clay with an admixture of poorly rounded pebbles & $<100$ \\
\hline 43 & $64^{\circ} 11.42^{\prime}$ & $37^{\circ} 36.65^{\prime}$ & Weakly clayey sand with coquina and pebbles & $<100$ \\
\hline 59 & $66^{\circ} 20.04^{\prime}$ & $35^{\circ} 32.02^{\prime}$ & Silt & 22000 \\
\hline 62 & $64^{\circ} 49.19^{\prime}$ & $35^{\circ} 43.33^{\prime}$ & Silt & 3600 \\
\hline 75 & $65^{\circ} 26.89^{\prime}$ & $39^{\circ} 04.18^{\prime}$ & Silt & 19900 \\
\hline 76 & $65^{\circ} 17.00^{\prime}$ & $39^{\circ} 16.62^{\prime}$ & Silt & 12000 \\
\hline 77 & $65^{\circ} 08.69^{\prime}$ & $39^{\circ} 16.95^{\prime}$ & Silt & 3000 \\
\hline 78 & $65^{\circ} 05.08^{\prime}$ & $39^{\circ} 44.15^{\prime}$ & Silt & $<100$ \\
\hline 88 & $64^{\circ} 55.49^{\prime}$ & $40^{\circ} 01.82^{\prime}$ & Fine-grained sand & 3900 \\
\hline \multicolumn{5}{|c|}{ Cruise 52 of R/V Ivan Petrov, the end of June to the beginning of July 2002} \\
\hline IvP 39 & $66^{\circ} 34.70^{\prime}$ & $33^{\circ} 47.10^{\prime}$ & Silt & 17100 \\
\hline IvP 40 & $66^{\circ} 25.70^{\prime}$ & $33^{\circ} 56.10^{\prime}$ & Silt & 13900 \\
\hline
\end{tabular}


The present-day hydrological region of the White Sea is mostly formed under the influence of the desalinating riverine runoff and the water exchange with the Barents Sea. To a significant extent, the abundant riverine runoff ( $225 \mathrm{~km}^{3} /$ year) [4] defines the regularities and particular features of the biochemical processes within its area. The particularity of the continental runoff lies, first of all, in the fact that all the rivers fall into the Dvina, Onega, and Mezen' bay, i.e., isolated sea areas, which determines the strongly irregular distribution of the salinity of the surface seawaters (Fig. 1). In so doing, the maximal runoff values, as well as those of the supply of particulate matter and nutrients, are observed in the springtime full warm-water period in May [4, 14].

The particulate matter is one of the principal forms of the matter transfer [13], and its elevated or reduced content in the water directly influence the ecological balance in the aquatic area. Phytoplankton, being a constituent of the particulate matter, is part of a long food chain, and its mineral particles (at their high contents) attenuate the solar flux to the deeper layers and retard the development of living organisms [13].

The water exchange with the Barents Sea is implemented via a narrow shallow-water strait - the Gorlo of the White Sea (Fig. 1). The permanent gravity current of the desalinated surface waters to the Barents Sea (with a discharge of $\sim 2200 \mathrm{~km}^{3} /$ year) runs along the Zimnii Coast of the White Sea. A reverse flow of heavy normally saline oceanic waters $\left(\sim 2000 \mathrm{~km}^{3} /\right.$ year $)$ is directed from the Barents Sea via the Gorlo; this way, approximately two-thirds of the deep White Sea water is annually renewed $[4,17,24]$.

The most important features of the hydrological regime of the White Sea is represented by tides; they reach their maximal heights (up to $10 \mathrm{~m}$ ) in Mezen' Bay. The intensive tidal movements provide strong vertical mixing of the waters; therefore, in the regions with relatively small sea depths (for example, the Gorlo and Onega and Mezen' bays), there is virtually no vertical stratification [2, 21, 24].

The summertime temperatures of the surface waters in the White Sea range from $+7 \mathrm{ai}+15^{\circ} \mathrm{C}$; in the wintertime, the temperatures fall down to $-1.6^{\circ} \mathrm{C}$ in the north and to $-1.7^{\circ} \mathrm{C}$ in the south. The riverine waters, which desalinate mainly the southeastern part of the sea (Fig. 1), provide additional conditions for the formation of the ice cover. From November to May, the sea is covered with drifting ice; in the bights near river mouths, fast ice is formed. Due to this reason, the White Sea is characterized by ice conditions that are more severe than those characteristic of the corresponding latitudes; this affects the dynamics of the biological productivity of phytocoenoses $[8,41,42]$. In addition to the local impacts, due to the exchange currents between the Barents and White seas, the sea ice that was formed in the inner basin is supplied to the Arctic Ocean, where it takes part in the global thermohaline cycling [22].

The spatial inhomogeneities in the halocline parameters are determined by the horizontal advection, the contacts between water masses of different origins, the riverine runoff distribution, and the intensity of the biochemical processes $[6,15]$. The horizontal circulation is the principal mechanism of the redistribution of elements over the sea area. According to different estimates, the mean annual productivity of phytoplankton of the White Sea varies from 13 to $95 \mathrm{~g} \mathrm{C}^{2} \mathrm{~m}^{2}[3,5-7$, $11,15,16,24]$ and features two seasonal peaks related to the spring and summer. In so doing, the peak of the dinoflagellate development follows the summertime peak of the development of diatomaceous algae.

\section{DINOCYSTS IN THE SURFACE SEDIMENT LAYER OF THE WHITE SEA}

Dinoflagellates represent one of the leading groups of phytoplankton and the principal biological producers of the White Sea [6, 8, 19, 20, 41, 42]. A revision of the systematic composition of the White Sea dinoflagellates $[19,42]$ showed that, with respect to the species number, the phytoplankton of the White Sea is rich as that of the Barents Sea [6]. Meanwhile, the reduced salinity of the White Sea waters hampers the development of selected stenohalyne species typical of the Barents Sea, while the high seasonal temperature gradients result in the absence of a series of cold-water Arctoboreal species. The flora of the White Sea contains no less than $50 \%$ of the Barents Sea species. According to the phytogeographical characteristics of the species [44], the planktonic flora of the White Sea belongs to the Arctoboreal domain; meanwhile, the proportion of Arctoboreal species (15\%) in the dinoflagellate composition is lower as compared to diatoms. The group of dinoflagellates, in contrast to the other phytoplankton components, features the highest proportion of boreal species $(13 \%)$. Along with this, the intensive water exchange with the Barents Sea provides a high species diversity of the Arctoboreal-tropical (14\% in the composition of dinophyta algae) and cosmopolitan (up to $28 \%$ ) species, which are never or rarely encountered in the Siberian seas of Eurasia [18].

\section{Quantitative Distribution of Dinocysts in the Sediments}

The sediments of the White Sea studied are distinguished by a relatively high diversity of the grain-size composition: from fine-grained sands to silty clays (Table 1). The sizes of dinoflagellate cysts range from 32 to $100 \mu \mathrm{m}$, which corresponds to the coarse-grained silt fraction of the White Sea sediments. The maximal dinocyst concentrations (up to 22000 cyst/g of dry sediment) were registered in the silty fractions of the surface sediments (Fig. 2), which confirms the regularities 


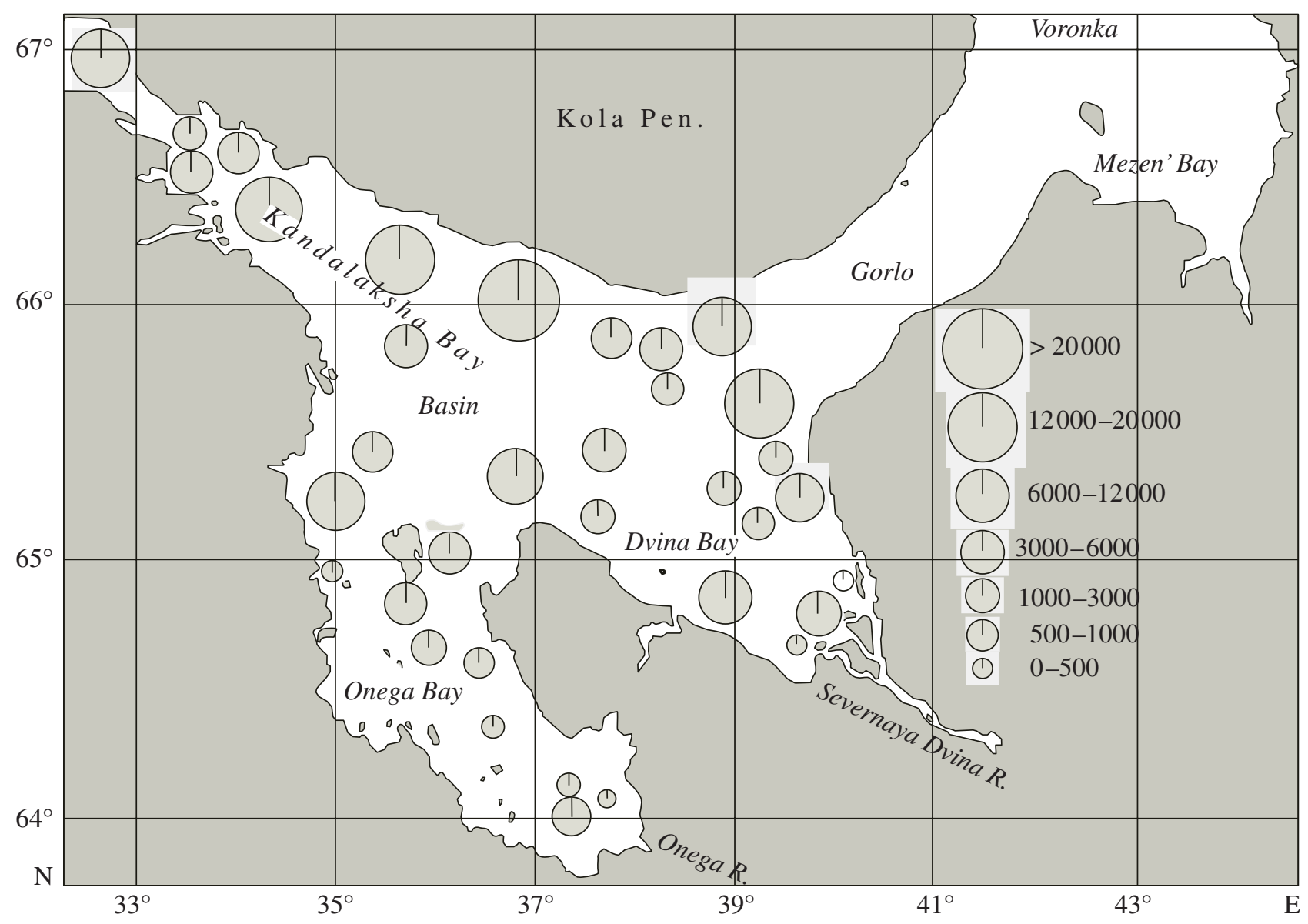

Fig. 2. Concentrations of dinoflagellate cysts in the surface sediments of the White Sea, cyst/g of dry sediment.

of the cyst distribution in the sediments revealed earlier [25]. The minimal concentrations $(<100$ cyst/g of dry sediment) were encountered in the fine-grained sands, which are usually perfectly washed. In the sands with various admixtures of silty and clayey matter, the concentrations of dinoflagellate cysts comprise from a few tens to 9500 cyst/g of dry sediment. From this fact, one can conclude that the enhanced dinocyst concentrations in the Central Basin and their reduced values in bays may be related to the grain-size composition of the White Sea sediments. Another factor that restricts the dinocyst contents in the sediments is the salinity of the surface seawater. Dinoflagellate cysts, as derivatives of marine phytoplankton, were encountered in the samples from the White Sea within the salinity interval from 15 to $25 \%$.

\section{Dinocyst Species in the Surface Sediments}

Thirteen dinocyst species were identified in the surface sediments of the White Sea (Table 2); this comprises approximately one-eighth of the dinoflagellate species ever registered in the plankton of this sea $[6,42]$.
The dominating species Operculodinium centrocarpum (Fig. 3) is a widely spread cosmopolitan species; this is confirmed by the ecology of this cell during its mobile stage (biological taxon Protoceratium reticulatum). This dinoflagellate species is a neritic species widely spread in seas and oceans of the boreal zone [30, 32, 34]. Another dominating cyst species Pentapharsodinium dalei (Scrippsiella trochoidea), in contrast to those previously mentioned, refers to the Peridinium group and is also a cosmopolite that is mostly distributed in the Northern Hemisphere [9]. Cysts of these species dominate (up to 76\%) in the northern and central regions of the White Sea. The species Spiniferites ramosus (Table 2) is also cosmopolitan and is most abundant in the zones of mixing of the surface waters $[32,43]$. In the White Sea, this species is most spread (up to $51 \%$ ) in the unstratified waters of Onega Bay. The heterotrophic marine species typical of polar and subpolar regions of the Arctic shelf seas such as Islandinium minutum and similar morphotypes (I. cezare and Echinidinium karaense) are widely spread in wide temperature and salinity ranges; they are capable of dwelling over 8-12 months under the conditions of sea ice cover $[9,27,32]$ and are most abundant (up to $33 \%$ ) 
Table 2. Species composition of dinoflagellate cysts in the White Sea

\begin{tabular}{|c|c|c|c|}
\hline Dinoflagellates cysts & Biological denomination & Ass. 1 & Ass. 2 \\
\hline Bitectatodinium tepikiense Wilson & Gonualax digitalis (Pouchet) Kofoid & + & \\
\hline Brigantedinium cariacoense (Wall). Reid & Protoperidinium cf. avellanum (Meunier) Balech & & + \\
\hline Brigantedinium simplex (Wall). Reid & Protoperidinium conicoides (Paulsen) Balech & & + \\
\hline Echinidinium karaense Head, Harland \& Matthiessen & Protoperidiniaceae & & + \\
\hline Islandinium minutum Harland \& Reid & Protoperidiniaceae & & + \\
\hline Islandinium? cezare de Vernal et al & Protoperidiniaceae & & + \\
\hline Operculodinium centrocarpum Wall \& Dale 1966 & $\begin{array}{l}\text { Protoceratium reticulatum (Claparende \& Lachmann) } \\
\text { Diesing }\end{array}$ & + & \\
\hline Cyst of Pentapharsodinium dalei Indelicato \& Loeblich & Scrippsiella trochoidea (Stein) Balech & + & \\
\hline Cyst of Polykrikos sp. Arctic morphotype Kunz-Pirrung & Polykrikos sp. Kunz-Pirrung & & \\
\hline Selenopemphix quanta (Bradford) Matsuoka & Protoperidinium conicum (Gran) Balech & & + \\
\hline Spiniferites elongatus Reid & Gonualax elongata (Reid) Ellegaard & + & \\
\hline Spiniferites ramosus Mantell & Gonualax spinifera (Claparende \& Lachmann) Diesing & + & \\
\hline Nematosphaeropsis labyrinthus (Ostenfeld) Reid & Gonualax spinifera (Claparende \& Lachmann) Diesing & + & \\
\hline
\end{tabular}

Note: Dinoflagellate associations: Ass. 1-autotrophic species; Ass. 2-heterotrophic species.

in the central and southern parts of the White Sea. The cysts of the neritc species Brigantedinium cariacoense and Brigantedinium simplex (Table 2, [35, 36]) widely spread in cold waters are characteristic of the northern and central regions of the sea, where their integrated abundance reaches $42 \%$. They refer to heterotrophic planktonic dinoflagellate species of the genus Protoperidinium. The species Selenopemphix quanta, which is highly tolerant to the salinity and temperature of the surface waters, features its highest abundances (up to $18 \%$ ) in Dvina Bay. In plankton, cells of this species are widely spread in cold, temperate, and warm waters [9].

Other dinocyst species are not abundant in the White Sea; their total content never exceeds $10 \%$. Meanwhile, their ecological and phytogeographical characteristics may provide additional information on the hydrological environments. Cysts of Polykrikos sp. Arctic morphotype, first identified in 2001 [31], are characteristic (up to $2 \%$ ) of Kandalaksha and Dvina bays. Cysts of Bitectatodinium tepikiense, which also refers to widely spread tropical-boreal notal species [9], are encountered in the northern part of the Basin and in Dvina Bay (up to 5-10\%). Species of the Nematosphaeropsis genus are cosmopolites and, at their planktonic stage, refer to the Gonualax spinifera species as well as species of the Spiniferites genus. In the sediments of the White Sea, they feature small abundances (up to 1\%) and are mostly encountered in the central parts of the sea.

\section{Regional Features of the Formation of Dinocyst Associations in the Surface Sediments}

Onega Bay is one of the most shallow-water bays of the sea. Its waters are formed under the influence of an intensive riverine runoff and of the waters of the Basin that penetrate into the most deep-water northern part of the bay via the Zapadnaya Solovetskaya Salma Strait [47]. The waters of the northern part are characterized by a higher salinity $(25-26 \%$ ) and a lower temperature [47]. Onega Bay is an estuary with the most complicated mosaic structure of the bottom topography, islands, and water stratification [37]. In this region, the composition of the dinocysts in the surface sediments is absolutely dominated by the autotrophic cosmopolitan species Operculodinium centrocarpum, Pentapharsodinium dalei, and Spiniferites spp. (up to 50\%) at high contents of heterotrophic species such as Islandinium minutum and Polykrikos sp. Arctic morphotype (Fig. 3). The maximal concentrations of Operculodinium centrocarpum and Pentapharsodinium dalei reach 1700 cyst/g of dry sediment at their relative proportion in the associations up to $37 \%$. The concentration of Spiniferites species (40-50\% of the associations) changes from 380 to $1400 \mathrm{cyst} / \mathrm{g}$ while moving toward the Solovetskie Islands. The prevalence of autotrophic species in the dinocyst associations of the surface sediments of Onega Bay is probably related to the composition of the phytoplankton and the temperature conditions favorable for the development of dinoflagellates during the vegetation period. Along with this, the elevated percentages of the heterotrophic species Islandinium minutum and 


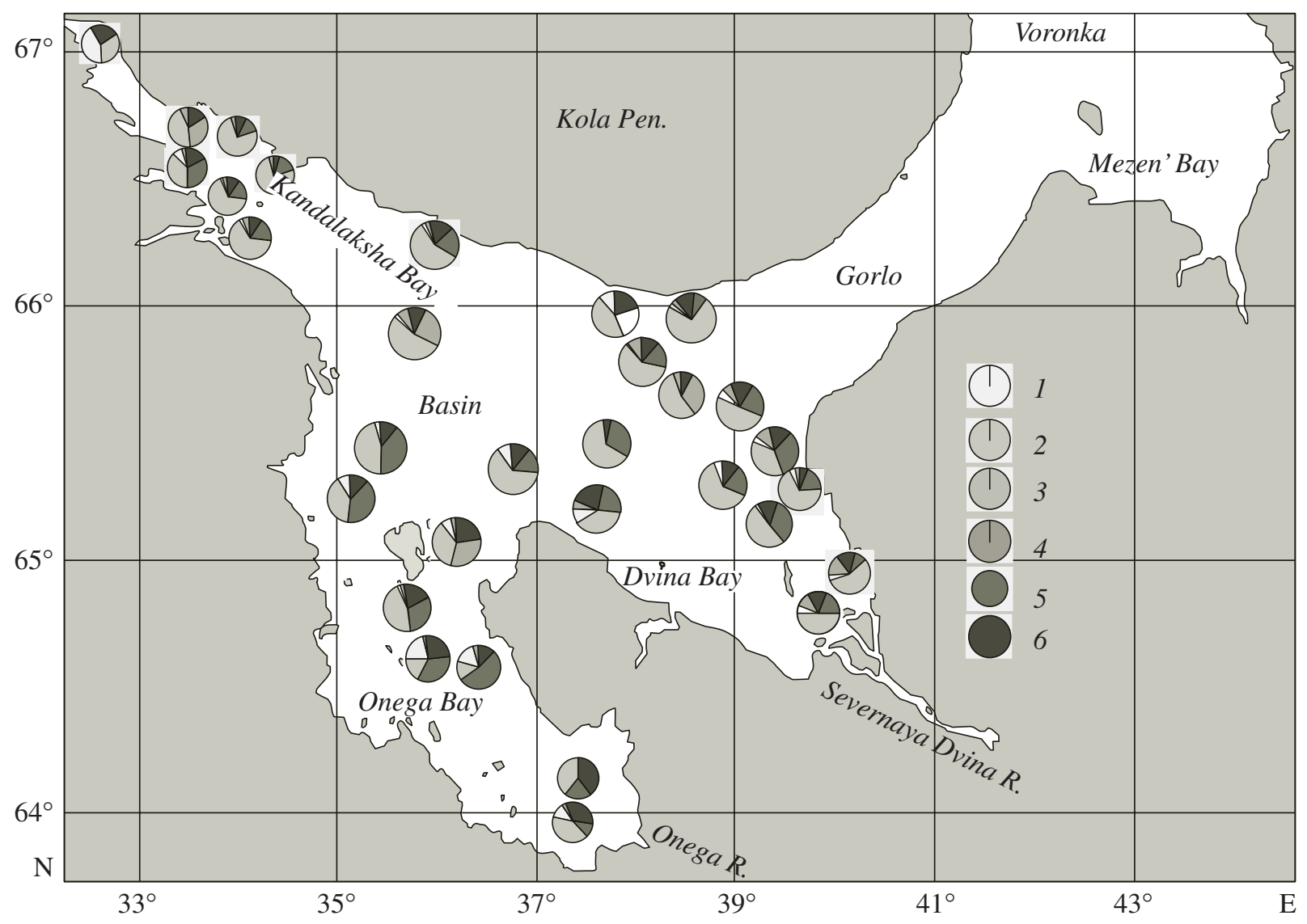

Fig. 3. Percentages of species and species groups of dinoflagellate cysts in the surface sediments of the White Sea, \% of the total dinocyst abundance in the samples: 1 -Brigantedinium sp. Wall 1965; 2 -Operculodinium centrocarpum sensu Wall \& Dale 1966; 3 - Selenopemphix quanta (Bradford 1975) Matsuoka 1985; 4 - Spiniferites elongatus Reid 1974; - Spiniferites spp. Mantell 1850; 5 - Islandinium cezare de Vernal 1989; - Islandinium minutum Harland \& Reid 1980; 6 - others.

close morphotypes (I. cezare, Echinidinium caraense) are probably caused by the elevated concentrations of particulate matter in the unstratified waters of the bay (up to $13-14 \mathrm{mg} / \mathrm{l}$ ) at the river-sea barrier during the period of the maximal development of planktonic dinoflagellates [13].

Kandalaksha Bay is the most deep-water bay characterized by a relatively quiet hydrological regime and a stable water stratification in the summertime period $[6,37]$. This wide and deep estuary features the most irregular coastline and inhomogeneous riverine runoff in different parts of the bay. In its water structure, three water masses are distinguished, namely, the surface, intermediate, and near-bottom water masses $[6,37]$. At the particulate matter concentrations from less than $0.2 \mathrm{mg} / \mathrm{l}$ in the central part of the bay to $1 \mathrm{mg} / \mathrm{l}$ in its top part [13], the dinocyst contents in the sediments of the central part of the bay reach 17100 cyst/g and increase to 22000 cyst/g toward the central depression (Fig. 2). The reason for the high concentration values in the deep-water areas of Kandalaksha Bay probably lies in the domination of silty sediments, in contrast to the shallow-water regions, where sandy fractions prevail
[47]. Autotrophic species such as Operculodinium centrocarpum and others dominate (up to 76\%) in the composition of the dinocyst associations in the surface sediments (Fig. 3), and their total concentrations in the sediments of the top part of the bay and in its middle most open part comprise 3000 and 13000 cyst/g, respectively. Along with the autotrophic species, heterotrophic species such as Islandinium minutum and its close morphotypes are present (up to $18 \%$ of the dinocyst composition at the total concentration up to 2500 cyst/g of dry sediment). Cysts of the tropicalboreal species Polykrikos sp. Arctic morphotype comprises $1-2 \%$. On the whole, the cysts of heterotrophic species are mainly confined to the shallow-water regions of the bay, in contrast to the cysts of autotrophic species, which are spread in the open parts of the sea characterized by a higher transparency (Fig. 3). This is also confirmed (Table 2) by the presence of the Spiniferites species (with a total content up to $32 \%$ in the dinocyst composition) confined to the areas with the minimal particulate matter contents near the Solovetskie Islands; this agrees with both satellite and expeditionary data [13]. Of heterotrophic species, Sele- 
nopemphix quanta (up to 10\%) is encountered in the top part of Kandalaksha Bay.

The Basin of the White Sea occupies the central part of the sea with sea depths of 100-300 m. The surface sediments of the Basin are characterized by constantly high dinocyst concentrations (more than 7000 cyst/g of dry sediment) (Fig. 2). The autotrophic species Operculodinium centrocarpum, Pentapharsodinium dalei, and others (up to $65 \%$ in the composition of the associations) and species of the Spiniferites genus (up to 40\%) dominate marking the zones with the lowest particulate matter contents (Fig. 3). In the central part of the Basin, Nematosphaeropsis sp. was noted; with respect to the feeding type, it is an analog of Operculodinium centrocarpum, although it dwells at greater depths [30, 32, 34]. Dvina Bay is located in the eastern part of the White Sea and represents a wide stratified estuary with the maximal runoff of the Severnaya Dvina River. Here, the particulate matter content is characterized by an increase in its concentration toward the Zimnii Coast, along which the major part of the riverine runoff is transported with concentrations from 1 to $5.56 \mathrm{mg} / \mathrm{l}$ in the autumn period [13]. With the distance from the river mouth toward the Basin of the White Sea, the dinocyst concentrations grow from 400 to $5000 \mathrm{cyst} / \mathrm{g}$, which generally corresponds to the changes in the grain-size composition of the sediments (Fig. 2). The maximal concentrations (up to 20000 cyst/g of dry sediment) were registered at the exit from the bay toward the Gorlo, where active water exchange with the Barents Sea occurs. Here, the dinocyst composition is dominated by the autotrophic species Operculodinium centrocarpum. In the top part of the bay, in the region of the operation of the marginal filter [12], an enhanced concentration (up to 40\%) of dinocysts of the heterotrophic species Islandinium minutum and Impagidinium pallidum, whose presence was related to the high water turbidity, and a decrease in the number of autotrophic species were noted.

\section{Principal Types of Dinocyst Associations} in the Surface Sediments of the White Sea

An analysis of the species composition of the dinoflagellate cysts and their abundances in the associations of the salinity layer of the bottom sediments of the White Sea allowed us to distinguish the following principal types of associations, whose spatial distribution is controlled, first, by the feeding type and composition of dinoflagellates that produce their cysts in the photic layer of the White Sea waters [28, 41].

The first (autotrophic) association includes species of the Gonyaulacaceae genus (Operculodinium centrocarpum, Spiniferites spp., and others) and cysts of the Peridinium (Pentapharsodinium dalei) genus with an autotrophic type of feeding; it almost universally dominates in the recent sediments of the White
Sea (Fig. 4, Table 2). Their maximum total contents in the composition of the associations are determined in the central part of the sea (up to 95\%) and in the region of the Solovetskie Islands (70\%), where the minimal particulate matter concentrations and, therefore, conditions more favorable for photosynthesis were observed.

The second (heterotrophic) association is mainly represented by cysts of the Protoperidinium genus such as Islandinium minutum $I$. cezare, Echinidinium karaense, Brigantedinium cariacoense, and Brigantedinium simplex (Fig. 4; Table 2). Their maximal contents in the composition of the associations (up to 47\%) are rather clearly confined to the inner parts of shallowwater unstratified bays with high water turbidity, first of all, to the near-mouth regions of the Onega and Severnaya Dvina rivers.

\section{CONCLUSIONS}

The studies of the dinocyst distribution in the surface sediments of the White Sea allowed us to reveal the following features of their species composition and quantitative content in the sediments:

(1) The concentrations of dinoflagellate cysts in the sediments of the White Sea are 20 times as low as those calculated previously for the Barents Sea [46] and are compatible with the values obtained for other Arctic seas, for example, for the Laptev Sea [30]. Their quantitative distribution over the White Sea is controlled by the grain-size composition of the sediments, which is responsible for the preservation and conditions of existence of cysts, and by the salinity of the surface waters, which governs the number of planktonic species of dinoflagellates.

(2) The qualitative composition of the dinocyst associations is directly related to the composition of dinoflagellates at the planktonic stage.

(3) The cysts of autotrophic species, which almost universally dominate in the sediments, reflect the hydrological conditions in the White Sea favorable for their development during the vegetation period.

(4) Studies of the relations between the cysts of autotrophic and heterotrophic dinoflagellate species showed that, in the top parts of shallow-water bays, where active water mixing occurs accompanied by an increase in the water turbidity and the riverine runoff is intensive and rich in microelements and phytoplankton, the proportion of heterotrophic species grows, while, in the open sea areas, representatives of autotrophic species of dinoflagellate cysts absolutely dominate.

\section{ACKNOWLEDGMENTS}

The authors are grateful to Academician A.P. Lisitsyn and V.P. Shevchenko for the materials presented for our studies and their comprehensive help during the preparation of the manuscript. We express our special grati- 


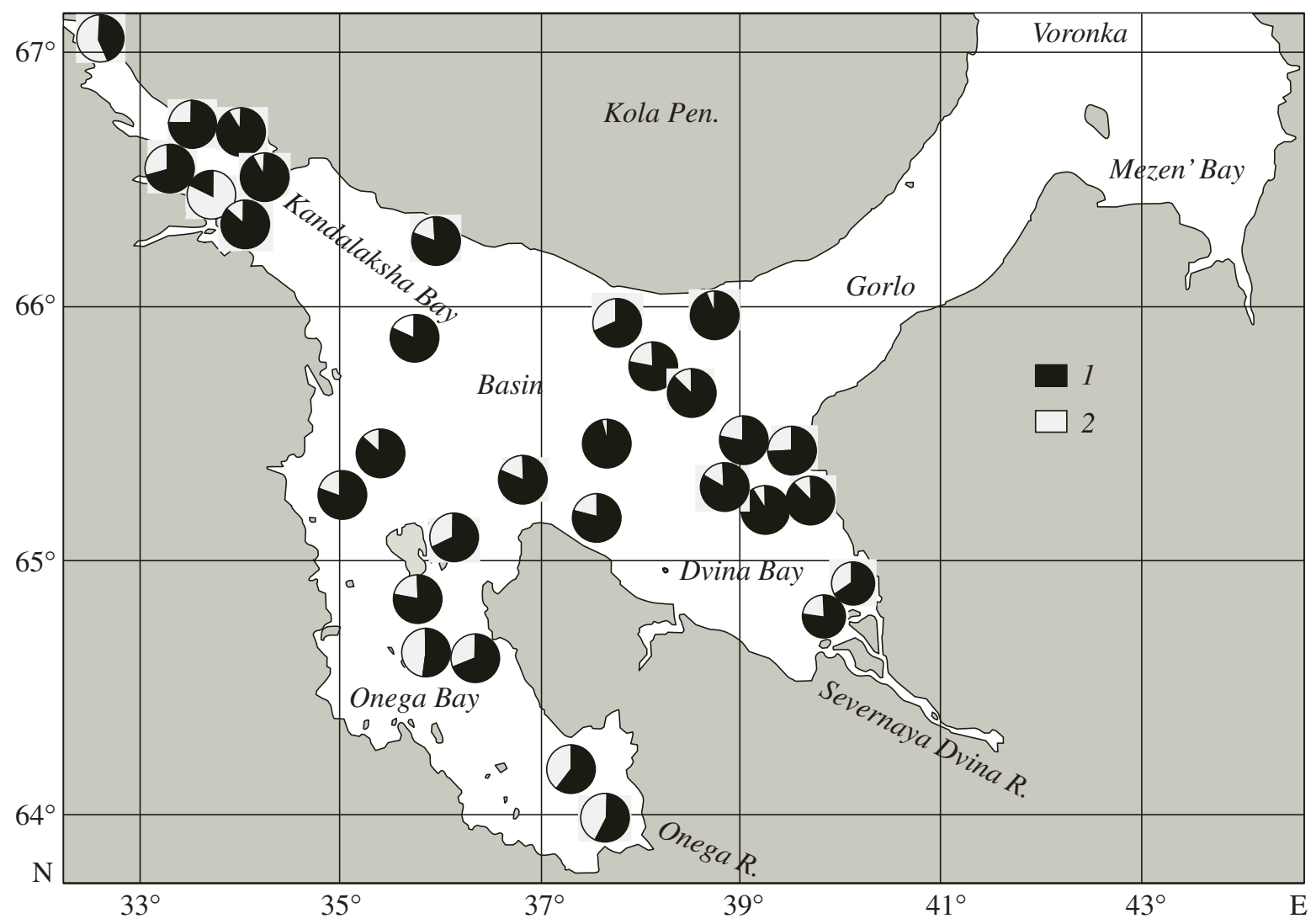

Fig. 4. Distribution of the principal types distinguished in the associations of dinoflagellate cysts in the surface sediments of the White Sea, $\%$ of the total dinocyst abundance in the samples. The circular diagrams represent the samples in which the statistically required cyst number (no less than 100) were counted. Association 1 -autotrophic species of dinoflagellate cysts; association 2heterotrophic species of dinoflagellate cysts.

tude to the crews of the R/Vs Professor Shtokman, Ivan Petrov, and Ekolog; to the scientific team of the Laboratory of Physical-Geological Studies of the Shirshov Institute of Oceanology of the RAS; personally, to A.N. Novigatskii for the lithological description of the sediments; and to V.N. Churun, a researcher of the Schmidt Russian-German Laboratory (AANII, St. Petersburg), for the vacuum drying of the samples.

This study was supported by the Russian Foundation for Basic Research (project nos. 06-05-65267 and 06-05-64815), by the Program for Support of Scientific Schools (project no. NSh-2236.2006.5), by Program 17 for Basic Research of the Presidium of the RAS (project no. 4.4), and by the "Nannoparticles in the Outer and Inner Geospheres" program of the Department of Earth Sciences of the RAS (project no. OSL06-16).

\section{REFERENCES}

1. A. D. Dobrovol'skii and B. S. Zalogin, Seas of the USSR (Mosk. Gos. Univ., Moscow, 1982) [in Russian].
2. The White Sea: Biological Resources and Problems of Their Rational Use, Part 1 (ZIN RAN, St. Petersburg, 1995) [in Russian].

3. Yu. A. Bobrov, M. P. Maksimov, and V. M. Savinov, "Primary Production of Phytoplankton," in The White Sea: Biological Resources and Problems of Their Rational Use, Part 1 (ZIN RAN, St. Petersburg, 1995) pp. 92-114 [in Russian].

4. The Seas of the USSR. Hydrometeorology and Hydrochemistry of the Seas. Vol. II. The White Sea, Issue 1, Hydrometeorological Conditions, Ed. by B. Kh. Glukhovskoi, (Gidrometeoizdat, St. Petersburg, 1991) [in Russian].

5. L. S. Zhitina and G. E. Mikhailovskii, "Ice and Planktonic Flora of the White Sea as an Object gfor Monitoring," in Biological Monitoring of Near-Shore Waters of the White Sea (Inst. Okeanol., Ross. Akad. Nauk SSSR, Moscow, 1990), pp. 41-49 [in Russian].

6. L. V. Il'yash, L. S. Zhitina, and V. D. Fedorov, Phytoplankton of the White Sea (Yanus-K, Moscow, 2003) [in Russian].

7. L. V. Il'yash, T. I. Kol'tsova, K. K. Sarukhan-Bek, et al., "Ecological-Coenotical Strategies of the White Sea Phytoplankton," Vestn. Mosk. Univ., Ser. 16. Biology, No. 2, 24-31 (1999). 
8. I. A. Kiselev, "Features of Phytoplankton Distribution in the White Sea," in Materials of Multidisciplinary Studies of the White Sea (Akad. Nauk SSSR, Moscow, 1957), No. 1, pp. 282-304 [in Russian].

9. G. V. Konovalova, Dinoflagellates (Dinorhuta) of the Far East Seas of Russia and Adjacent Areas of the Pacific Ocean (Dal'nauka, Vladivostok, 1998) [in Russian].

10. B. I. Koshechkin, "Recent Structure Pattern of the Northeastern Part of the Baltic Crystalline Shield," in Nature and Economy of the North (Kol'skii nauchnyi tsentr AN SSSR, Apatity, 1976), No. 4, pp. 3-11 [in Russian].

11. L. L. Kuznetsov and E. V. Shoshina, Phytocoenoses of the Barents Sea (Physiological and Structural Characteristics) (Izd. KNTs RAN, Apatity, 2003) [in Russian].

12. A. P. Lisitsyn, "Marginal Filter of the Oceans," Okeanologiya 34 (5), 735-747 (1994).

13. A. P. Lisitsyn, V. P. Shevchenko, V. I. Burenkov, et al., "Particulate Matter and Hydrooptics of the White Sea: New Regularities in the Quantitative Distribution and Grain-Size Composition," in Urgent Problems of Oceanology (Nauka, Moscow, 2003), pp. 554-605 [in Russian].

14. M. P. Maksimova, "Contents of Nutrients and Balance of Nitrogen, Phosphorus, and Silicon in the White Sea," Okeanologiya 18 (1), 58-63 (1978).

15. M. P. Maksimova, "Hydrochemistry of the White Sea," in The Seas of the USSR. Hydrometeorology and Hydrochemistry of the Seas. Vol. II. The White Sea, Issue 2, (Gidrometeoizdat, St. Petersburg) pp. 8-193 [in Russian].

16. I. A. Naletova, V. V. Sapozhnikov, and M. P. Metreveli, "Production-Destruction Processes in the White Sea," in Multidisciplinary Studies of the White Sea Ecosystem (VNIRO, Moscow, 1994), pp. 76-83 [in Russian].

17. E. N. Nevesskii, V. S. Medvedev, and V. V. Kalinenko, The White Sea. Sedimentogenesis and Evolution History in the Holocene (Nauka, Moscow, 1977) [in Russian].

18. Yu. B. Okolodkov, Extended Abstract of Doctoral Dissertation in Biology (St. Petersburg, 2000).

19. G. I. Semina and O. M. Sergeeva, "Planktonic Flora and Biogeographic Characteristic of the White Sea Phytoplankton," in Ecology and Physiology of Animals and Plants of the White Sea (Mosk. un-t, Moscow, 1983), pp. 3-17 [in Russian].

20. O. M. Sergeeva, "Distribution of Phytoplankton in the White Sea Basin in July 1972 and August 1973," in Phytoplankton Studies in the System of Monitoring of the Baltic Sea and Other Seas of the USSR (Gidrometeoizdat, Moscow, 1991), pp. 82-94 [in Russian].

21. F. A. Shcherbakov, "The White Sea," in Geoecology of the Shelf and Coasts of the Seas of Russia, Ed. by N. A. Aibulatov (Noosfera, Moscow, 2001) [in Russian].

22. K. Aagaard and E. C. Carmack, "The Arctic Ocean and Climate: A Perspective," in The Polar Oceans and the Role in Shaping the Global Environment (The Nansen centennial volume, Geophysical Monograph, 85 (1994)), pp. 5-20.
23. M. S. Barss and G. L. Williams, Palynology and Nannofossil Processing Techniques (Geol. Surv. Can, 1973).

24. V. Ya. Berger and A. D. Naumov, "General Features of the White Sea. Morphology, Sediments, Hydrology, Oxygen Conditions, Nutrients, and Organic Matter,' Berichte zur Polarfoschung, No. 359, 3-9 (2000).

25. B. Dale, "Cyst Formation, Sedimentation and Preservation: Factors Affecting Dinoflagellate Assemblages in Recent Sediments from Trondheimsfjord, Norway," Review of Palaeobotany and Palynology 22, 39-60 (1976).

26. A.-M. Dale and B. Dale, "Dinoflagellate Contributions to the Open Ocean Sediment Flux," in Dinoflagellate Contributions to the Deep Sea (Ocean Biocoenosis Series 5 (1992), pp. 1-31.

27. A. De Vernal, M. Henry, J. Matthiessen, et al., "Dinoflagellate Cyst Assemblages As Tracers of SeaSurface Conditions in the Northern North Atlantic, Arctic, and Sub-Arctic Seas: The New $N=677$ Database and Its Application for Quantitative Palaeoceanographic Reconstruction,” J. Quaternary Sci. 16, 681-698 (2001).

28. J. D. Dodge, "Biogeography of Marine Armored Dinoflagellates and Dinocysts in the NE Atlantic and North Sea," Review of Palaeobotany and Palynology 84, 169-180 (1994).

29. V. V. Gordeev, J. M. Martin, I. S. Sidorov, et al., "A Reassessment of the Eurasian River Input of Water, Sediment, Major Elements, and Nutrients to the Arctic Ocean," Am. J. Sci. 296, 664-691 (1996).

30. M. Kunz-Pirrung, "Distribution of Aquatic Palynomorphs in Surface Sediments from the Laptev Sea, Eastern Arctic Ocean," in Land-Ocean System in the Siberian Arctic: Dynamics and History (Springer, Berlin, 1999), pp. 561-575.

31. M. Kunz-Pirrung, "Dinoflagellate Cyst Assemblages in Surface Sediments of the Laptev Sea Region (Arctic Ocean) and Their Relation to Hydrographic Conditions," J. Quaternary Sci. 16, 637-649 (2001).

32. F. Marret and K. Zonneveld, "Atlas of Modern OrganicWalled Dinoflagellate Cyst Distribution," Review of Palaeobotany and Palynology 125, 1-200 (2003).

33. J. Matthiessen, "Distribution Patterns of Dinoflagellate Cysts and Other Organic-Walled Microfossils in Recent Norwegian-Greenland Sea Sediments," Mar. Micropalaeontology 24, 307-334 (1995).

34. J. Matthiessen, M. Kunz-Pirrung, and P. J. Mudie, "Fresh Water Chlorophycean Algae in Recent Marine Sediments of the Beaufort, Laptev, and Kara Seas (Arctic Ocean) As Indicators of River Runoff," International Journal of Earth Sciences 89, 470-485 (2000).

35. P. J. Mudie, R. Harland, J. Matthiessen, et al., "Marine Dinoflagellate Cysts and High Latitude Quaternary Paleoenvironmental Reconstructions: An Introduction," J. Quaternary Sci. 16, 595-602 (2001).

36. P. J. Mudie, "Circum-Arctic Quaternary and Neogene Marine Palynofloras: Paleoecology and Statistical Analysis," in Neogene and Quaternary Dinoflagellate Cysts and Acritarchs (American Association of Stratigraphic Palynologists Foundation, Dallas, 1992), pp. 347-390. 
37. A. N. Pantyulin, "Hydrological System of the White Sea," Oceanology 43 Suppl., S1-S14 (2003).

38. D. Phipps and G. Playford, "Laboratory Techniques for Extraction of Palynomorphs from Sediment," Pap. Dept Geol Univ. 11 (1), 1-23 (1984).

39. E. I. Polyakova, R. N. Dzhinoridze, T. S. Novichkova, et al., "Diatoms and Palynomorphs in the White Sea Sediments As Indicators of Ice and Hydrological Conditions," Oceanology 43 Suppl., S144-S158 (2003).

40. T. Radi, A. de Vernal, and O. Peyron, "Relationships between Dinoflagellate Cyst Assemblages in Surface Sediment and Hydrographic Conditions in the Bering and Chukchi Seas," J. Quaternary Sci. 16, 667-680 (2001).

41. T. N. Ratkova, "The White Sea Basin Phytoplankton: A Review," Berichte zur Polarfoschung 359, 23-30 (2000).

42. T. N. Ratkova, "Phytoplankton Composition in the White Sea Basin in Summer-Autumn 1998 and 1999," Berichte zur Polarfoschung 359, 97-100 (2000).
43. A. Rochon, A. de Vernal, J-L. Turon, et al., Distribution of Dinoflagellate Cysts in Surface Sediments from the North Atlantic Ocean and Adjacent Basins and Quantitative Reconstruction of Sea-Surface Parameters (American Association of Stratigraphic Palynologists Contribution Series 35, 1999).

44. H. I. Semina, "An Outline of the Geographical Distribution of Oceanic Phytoplankton," Advances in Marine Biology 32, 527-563 (1997).

45. J. Stockmarr, "Tablets with Spores Used in Absolute Pollen Analysis," Pollen Spores 13 (4), 616-621 (1971).

46. E. Voronina, L. Polyak, A. de Vernal, et al., "Holocene Variations of Sea-Surface Conditions in the Southeastern Barents Sea, Reconstructed from Dinoflagellate Cyst Assemblages," J. Quaternary Sci. 16, 717-726 (2001).

47. White Sea. Ecology and Environment, Ed. by V. Berger and S. Dahle (St. Petersburg-Tromso, 2001). 